Berkala Ilmu Perpustakaan dan Informasi, Vol. 14, No. 2, Desember 2018, Hal. 148-163 DOI: 10.22146/bip.27495

ISSN 1693-7740 (Print), ISSN 2477-0361 (Online)

Tersedia online di https://jurnal.ugm.ac.id/bip

\title{
Evaluasi kesesuaian penentuan beban kerja (PBK) dengan angka kredit pada sasaran kinerja pegawai (SKP) pustakawan tingkat ahli Universitas Gadjah Mada
}

\author{
Endah Choiriyah $^{1}$, Umi Sugiyanti $^{1}$ dan Laili Hidayah ${ }^{1}$ \\ ${ }^{1}$ Perpustakaan Universitas Gadjah Mada \\ E-mail: endahpuspita@ugm.ac.id
}

Naskah diterima: 15 Agustus 2017, direvisi: 2 Juli 2018, disetujui: 27 Juli 2018

\begin{abstract}
ABSTRAK
Pendahuluan. Penelitian ini membahas tentang kesesuaian Penentuan Beban Kerja (PBK) dengan Angka Kredit pada Sasaran Kinerja Pegawai (SKP) Pustakawan Tingkat Ahli di lingkungan UGM. Tujuan penelitian ini untuk mengevaluasi kesesuaian penentuan beban kerja (SKR) dengan jumlah angka kredit yang digunakan sebagai acuan dalam menyusun SKP Target.

Metode Penelitian. Metode penelitian yang digunakan yaitu metode penelitian kualitatif, dengan melakukan wawancara pada Tim Pembuat SKR; Tim Manajemen Perpustakaan dan kuesioner dengan 50 Pustakawan Ahli menggunakan Google Forms (http://bit.ly/2svxQ7r).

Data Analisis. Data analisis dengan menggunakan Google Forms Survey.

Hasil dan Pembahasan. Hasil penelitian menunjukkan bahwa 11 pustakawan ahli (22,9\%) mengalami kesulitan dalam membuat SKP; 11 pustakawan ahli $(31,4 \%)$ masih mengalami kesulitan dalam memenuhi Waktu Kerja Efektif(WKE) sebesar 1250 jam; 24 pustakawan ahli (66,7\%) menyatakan bahwa Penentuan Waktu pada ButirButir Kegiatan dalam SKP belum sesuai; 18 pustakawan ahli (52,9\%) merasa kesulitan dalam menyesuaikan jumlah angka kredit dengan jumlah jam kerja; 20 pustakawan ahli (57,2\%) menyatakan belum ada pedoman dalam penentuan waktu (SKR).

Kesimpulan dan Saran. Penentuan besarnya SKR ditentukan berdasarkan kesepakatan Tim; besarnya SKR dalam butir-butir kegiatan belum semua sesuai dengan kegiatan yang ada di lapangan.
\end{abstract}

Kata Kunci : SKP; SKR; Pustakawan Ahli; Penentuan Beban Kerja (PBK); Angka Kredit

\begin{abstract}
Introduction. The study discusses Workload Determination (Penentuan Beban Kerja/PBK) towards Credit Score (Angka Kredit) listed within the university system to examine Staff Target Performance (Sasaran Kinerja Pegawai/SKP) of skilled Librarians at the Library, Universitas Gadjah Mada.

Data Collection Method. The required number of Credit Score in SKP matrix were evaluated by using qualitative perspective. The data was collected by interviewing SKR Compiler Team; Library Management Team, as well asquestioners distributed to 50 Skilled Librarians through Google Forms.

Data Analysis. The data was analysed by using some features from Google Forms Survey.

Results and Discussions. The results showed that 11 skilled librarians (22.9\%) had difficulties in creating SKP; 11 skilled librarians (31.4\%) still had problems in meeting Effective Working Time of 1250 hours; 24 skilled librarians (66.7\%) stated that the timing of items in SKP was not suitable; 18 skilled librarians (52.9\%) found difficulties to adjust the number of credits and the number of working hours; 20 skilled librarians (57.2\%) stated that there was limited guidance in the timing and activities in SKP.

Conclusion. The required amount of timing was decided based on team's agreement however in reality, the implementation was still in question.
\end{abstract}

Keywords: SKP; SKR; Skilled Librarians ; Determination of Workload;; Credit Score 


\section{A. PENDAhULUAN}

Pustakawan merupakan salah satu sumber daya yang menggerakkan sumber daya lain dalam organisasi perpustakaan yang memungkinkan perpustakaan dapat berperan secara optimal di dalam melaksanakan tugas pokok dan fungsinya, sehingga pustakawan menjadi ujung tombak keberhasilan dalam penyebarluasan informasi di perpustakaan (Anonim, 2014). Menurut Toyang (2007:15), hakekat sumber daya manusia (SDM) dalam suatu organisasi (perpustakaan) merupakan kunci menentukan keberhasilan organisasi. SDM menjadi titik sentral penyelenggara seluruh fungsi-fungsi manajerial. Dalam UU No.43 Tahun 2007, juga dikatakan bahwa pustakawan adalah seseorang yang memiliki kompetensi yang diperoleh melalui pendidikan dan/atau pelatihan kepustakawan serta mempunyai tugas dan tanggung jawab untuk melaksanakan pengelolaan dan pelayanan perpustakaan. Perpustakaan sebagai salah satu garda terdepan dalam peningkatan kualitas sumber daya manusia melalui penyediaan koleksi bahan pustaka dan non-pustaka sebagai sumber belajar, sumber informasi, dan ilmu pengetahuan memiliki peran strategis dalam pelaksanaan pembangunan kualitas sumber daya manusia (SDM) (Romadhoni, 2015:126). Pustakawan dituntut untuk senantiasa meningkatkan kompetensi dan profesionalisme dalam melaksanakan tugas dan fungsinya (Nashihuddin, 2015).

Perpustakaan Universitas Gadjah Mada (UGM) mempunyai pustakawan sebanyak 81 orang yang terdiri dari 51 pustakawan tingkat ahli dan 30 pustakawan tingkat terampil. Pustakawan UGM mempunyai kewajiban untuk membuat Sasaran Kerja Pegawai (SKP) Target sebagai rencana kerja selama satu tahun. SKP Target berisi butir-butir rincian kegiatan pustakawan yang lengkap dengan Satuan Kerja Rata-rata (SKR) sebagai Penentuan Beban Kerja (PBK). Seorang Aparatur Sipil Negara mendapat beban Waktu Kerja Efektif (WKE) dalam setahun sebesar 1250 jam. Tidak mudah bagi pustakawan untuk memenuhi jumlah ini karena apabila jumlah jam terpenuhi maka angka kredit yang diperoleh akan melambung, melampaui batas kewajaran.

Penentuan SKR dinilai masih rendah tidak seimbang dengan perolehan angka kredit. Hal ini mengakibatkan pustakawan menambah pekerjaan lain-lain sebagai tugas penunjang di luar butir-butir yang telah ditentukan (Gambar 1). Sebagai ilustrasi pada Tabel 1. contoh data WPT Pustakawan ahli UGM dengan inisial E, U dan $\mathrm{N}$.

Berdasarkan data pada Tabel 1. menunjukkan bahwa pada tahun 2017, Pustakawan E mengumpulkan angka kredit sebesar 89,80. Hal ini memungkinkan yang bersangkutan bisa naik jabatan ke tingkat yang lebih tinggi dalam waktu kurang dari 2 tahun. Sedangkan U dalam satu tahun bisa mengumpulkan angka kredit sebanyak 90,065. Hal ini memungkinkan yang bersangkutan bisa naik jabatan dalam waktu satu tahun dan mempunyai kelebihan angka kredit sebanyak 40,065. Begitu juga untuk $N$ dalam satu tahun bisa mengumpulkan angka kredit sebanyak 88,09 . Hal ini memungkinkan yang bersangkutan bisa naik jabatan dalam waktu satu tahun dan mempunyai kelebihan nilai sebanyak 38,09.

Dari data tersebut, menunjukkan bahwa dalam pengisian SKP muncul berbagai variasi seperti realisasi yang jauh melampaui target, angka kredit yang diperoleh dalam kurun waktu satu tahun menjadi tinggi, tidak sesuai dengan kenyataan yang terjadi selama ini. Rata-rata kenaikan jabatan pustakawan di UGM lebih dari 2 tahun.

Di samping itu PBK menjadi acuan bagi pustakawan dalam menyusun SKP Target. Apabila penentuan ini tidak sesuai maka pustakawan akan mengalami kesulitan dalam menyusun SKP Target (Gambar 2).

Berdasarkan latar belakang, penelitian ini belum pernah dilakukan oleh peneliti sebelumnya, sebagai upaya untuk mengevaluasi kesesuaian SKR dalam PBK dengan jumlah angka kredit yang diperoleh pustakawan tingkat ahli selama satu tahun. Permasalahan dalam penelitian ini, permasalahan apa saja yang dihadapi pustakawan tingkat ahli dalam 
menyusun SKP Target; bagaimana cara menentukan besarnya SKR sebagai beban kerja yang harus dipenuhi oleh pustakawan?; Mengapa besarnya SKR dalam PBK tidak seimbang dengan jumlah angka kredit yang dibutuhkan oleh pustakawan tingkat ahli?. Penelitian ini bertujuan untuk mengetahui permasalahan yang dihadapi pustakawan tingkat ahli dalam menyusun SKP Target; Untuk mengevaluasi besarnya SKR pada butir-butir kegiatan dalam SKP, Untuk mengetahui tingkat kesesuaian antara SKR dengan angka kredit; pustakawan tingkat ahli; Untuk memberi kemudahan pada pustakawan dalam penyusunan SKP Target; Memberi masukan kepada pimpinan dalam menentukan PBK; Untuk menyamakan persepsi dalam penyusunan SKP target.

\section{B. TINJAUAN PUSTAKA Pengertian Evaluasi}

Pengertian evaluasi dalam kamus besar bahasa Indonesia berarti penilaian; hasil. Menurut Bryan \& White (1987), evaluasi adalah upaya untuk mendokumentasi dan melakukan penilaian tentang apa yang terjadi dan juga mengapa hal itu terjadi, evaluasi yang paling sederhana dengan mengumpulkan informasi tentang keadaan sebelum dan sesudah pelaksanaan suatu program/rencana. Pengertian evaluasi menurut Charles O Jones dalam Aprilia (2009) adalah "evaluation is an activity which can contribute greatly to the undestanding and improvement of policy development and implementation" (evaluasi adalah kegiatan yang dapat menyumbangkan pengertian yang besar nilainya dan dapat pula membantu penyempurnaan pelaksanaan kebijakan beserta perkembangannya). Pengertian tersebut menjelaskan bahwa kegiatan evaluasi dapat mengetahui apakah pelaksanaan suatu program sudah sesuai dengan tujuan utama, yang selanjutnya kegiatan evaluasi tersebut dapat menjadi tolok ukur apakah suatu kebijakan atau kegiatan dapat dikatakan layak diteruskan, perlu diperbaiki atau dihentikan kegiatannya.

Menurut PP No.39 Tahun 2006 tentang Tata Cara Pengendalian dan Evaluasi Pelaksanaan Rencana Pembangunan, Evaluasi adalah rangkaian kegiatan membandingkan realisasi masukan (input), keluaran (output), dan hasil (outcome) terhadap rencana dan standar. Sedangkan menurut Ernest R. Alexander dalam Aminudin (2007), metode evaluasi dapat diklasifikasikan menuju lima yaitu:

1) Before and after comparisons, metode ini mengkaji suatu objek penelitian dengan membandingkan antara kondisi sebelumnya dan kondisi sesudahnya.

2) Actual versus planned performance comparisons, metode ini mengkaji suatu obyek penelitian dengan membandingkan kondisi yang ada (actual) dengan ketetapan perencanaan yang ada (planned)

3) Experimental (controlled) model, model yang mengkaji suatu obyek penelitian dengan melakukan percobaan yang terkendali untuk mengetahui kondisi yang diteliti.

4) Quasi experimental models, merupakan metode yang mengkaji suatu objek penelitian dengan melakukan percobaan tanpa melakukan pengontrolan/ pengendalian terhadap kondisi yang diteliti.

5) Cost oriented models, metode ini mengkaji suatu objek penelitian yang hanya berdasarkan pada penilaian biaya terhadap suatu rencana.

Menurut peraturan tersebut di dalam pelaksananya, kegiatan evaluasi dapat dilakukan pada berbagai tahapan yang berbeda, yaitu:

1. Evaluasi pada Tahap Perencanaan (ex-ante), yaitu evaluasi dilakukan sebelum ditetapkannya rencana pembangunan dengan tujuan untuk memilih dan menentukan skala prioritas dari berbagai alternatif dan kemungkinan cara mencapai tujuan yang telah dirumuskan sebelumnya.

2. Evaluasi pada Tahap Pelaksanaan (ongoing), yaitu evaluasi dilakukan pada saat pelaksanaan rencana pembangunan untuk menentukan tingkat kemajuan pelaksanaan rencana dibandingkan dengan rencana yang telah ditentukan sebelumnya, dan

3. Evaluasi pada Tahap Pasca Pelaksanaan (expost), yaitu evaluasi yang dilaksanakan setelah pelaksanaan rencana berakhir, yang 
diarahkan untuk melihat apakah pencapaian (keluaran/hasil/dampak) program mampu mengatasi masalah pembangunan yang ingin dipecahkan. Evaluasi ini digunakan untuk menilai efisiensi (keluaran dan hasil dibandingkan masukan), efektivitas (hasil dan dampak sasaran), ataupun manfaat (dampak terhadap kebutuhan) dari suatu program.

\section{Pengertian Sasaran Kerja Pegawai (SKP)}

Dalam Peraturan Pemerintah RI No.46 Tahun 2011 tentang Penilaian Prestasi Kerja Pegawai Negeri Sipil menjelaskan bahwa untuk mewujudkan pembinaan Pegawai Negeri Sipil berdasarkan penilaian Prestasi Kerja dan sistem karir yang dititikberatkan pada sistem prestasi kerja, perlu dilakukan penilaian prestasi kerja. Penilaian prestasi kerja PNS merupakan suatu proses penilaian secara sistematis yang dilakukan oleh pejabat penilai terhadap sasaran kerja pegawai dan perilaku kerja PNS. Prestasi kerja adalah hasil kerja yang dicapai oleh setiap PNS pada satuan organisasi sesuai dengan sasaran kerja pegawai dan perilaku kerja. SKP adalah rencana kerja dan target yang akan dicapai oleh seorang PNS.

Ketentuan SKP:

1. Setiap PNS wajib menyusun SKP

2. SKP memuat tugas jabatan dan target yang harus dicapai dalam kurun waktu penilaian yang bersifat nyata dan dapat diukur.

3. SKP harus disetujui dan ditetapkan oleh pejabat penilai

4. SKP yang disusun oleh PNS tidak disetujui pejabat penilai maka keputusannya diserahkan kepada atasan pejabat penilai dan bersifat final.

5. SKP ditetapka setiap tahun pada bulan Januari.

6. Apabila terjadi perpindahan pegawai setelah bulan Januari maka yang bersangkutan tetap menyusun SKP pada awal bulan sesuai dengan surat perintah melaksanakan tugas atau surat perintah menduduki jabatan

7. PNS yang tidak menyusun SKP dijatuhi hukuman disiplin sesuai dengan ketentuan peraturan perundang-undangan yang mengatur mengenai disiplin PNS.
8. SKP memuat kegiatan tugas jabatan dan target yang harus dicapai. Setiap kegiatan tugas jabatan yang akan dilakukan harus berdasarkan pada tugas dan fungsi, wewenang, tanggung jawab, dan uraian tugas yang telah ditetapkan dalam Struktur Organisasi dan Tata Kerja (STOK).

Peraturan Menteri Pendayagunaan Aparatur Negara dan Reformasi Birokrasi RI No.9 Tahun 2014 tentang Jabatan Fungsional Pustakawan adalah jabatan yang mempunyai ruang lingkup, tugas, tanggung jawab, wewenang dan hak untuk melaksanakan kegiatan kepustakawanan. Pustakawanan adalah Pegawai Negeri Sipil (PNS) yang diberi tugas, tanggung jawab, wewenang dan hak untuk melaksanakan kegiatan kepustakawanan.

Pustakawan tingkat ahli dengan pendidikan Sarjana (S1)/Diploma IV (D.IV) sebagaimana tercantum dalam lampiran $\mathrm{V}$ yang merupakan bagian tidak terpisahkan dari Peraturan Menteri ini; d. Pustakawan tingkat ahli dengan pendidikan Magister (S2) sebagaimana tercantum dalam lampiran VI yang merupakan bagian tidak terpisahkan dari Peraturan Menteri ini; dan e. Pustakawan tingkat ahli dengan pendidikan doktor (S3) sebagaimana tercantum dalam lampiran VI yang merupakan bagian tidak terpisahkan dari peraturan menteri ini.

\section{METODE PENELITIAN}

Penelitian ini akan dilakukan 3 tahap yaitu tahap persiapan, tahap pelaksanaan dan tahap penyelesaian.

1. Tahap persiapan meliputi menyiapkan daftar pertanyaan, perijinan.

2. Tahap pelaksanaan meliputi pengumpulan data, dengan observasi, wawancara dan catatan lapangan.

3. Tahap penyelesaian meliputi analisis data dan penyelesaian administrasi.

Penelitian ini menggunakan metode penelitian kualitatif yang menekankan pada analisis kealamiahan sumber data. Metode penelitian kualitatif merupakan sebuah cara yang lebih menekankan pada aspek pemahaman secara mendalam terhadap suatu permasalahan. Penelitian kualitatif ialah penelitian riset yang bersifat deskriptif dan cenderung menggunakan 
analisis serta lebih menonjolkan proses dan makna. Tujuan dari metodologi ini ialah pemahaman secara lebih mendalam terhadap suatu permasalahan yang dikaji. Dan data yang dikumpulkan lebih banyak kata ataupun g a mbar-gambar daripada angka (https://id.wikipedia.org/wiki/Penelitian_Kuali tatif).

\section{Teknik Pengambilan Sampel}

Sampel sumber data dipilih secara purposive dan menggunakan teknik penentuan sampel snowball sampling. Peneliti menentukan sendiri sampel yang diambil karena mempunyai pertimbangan tertentu. Jadi, sampel diambil tidak secara acak tetapi ditentukan sendiri oleh peneliti yaitu Tim Manajemen sebanyak 6 orang meliputi Kepala Perpustakaan, Kepala Bidang Layanan, Kepala Bidang TI dan Jaringan, Hindar Purnomo (Koordinar Pustakawan/Purna Tugas), Sri Rumani (Tim Penilai Angka Kredit Pustakawan), Nurhayati (pengganti Hindar P.) dan 50 pustakawan ahli.

\section{Metode Pengumpulan Data}

Teknik pengumpulan data yang dilakukan yaitu dengan pengamatan secara langsung/observasi participant, wawancara mendalam dengan menggunakan panduan wawancara, studi dokumentasi.

Sumber data penelitian menggunakan sumber data primer dan sumber data sekunder. Sumber data primer diperoleh dengan cara melakukan wawancara langsung dengan Pimpinan Perpustakaan UGM untuk menggali informasi dalam penentuan beban kerja pada butir-butir kegiatan yang ada di SKP dan pustakawan tingkat ahli baik yang ada di Perpustakaan Pusat maupun Perpustakaan Fakultas untuk menggali permasalahan yang dihadapi, mencari informasi tentang kesesuaian antara PBK dengan angka kredit pustakawan tingkat ahli. Jumlah sumber informan dari pustakawan sebanyak $50 \%$ dari total pustakawan tingkat ahli. Data Sekunder diperoleh dengan melakukan penelaahan pada web HRIS UGM https://hris.simaster.ugm.ac.id dan Peraturan Pemerintah RI No.46 Tahun 2011 tentang Penilaian Prestasi Kerja Pegawai Negeri Sipil. Sumber data sekunder merupakan sumber yang tidak langsung memberikan data kepada peneliti/pengumpul data, yaitu lewat orang lain atau lewat dokumen.

Selain melakukan wawancara dengan narasumber, peneliti juga menyebarkan kuesioner kepada pustakawan ahli melalui google form de ngan a 1 a m a t http://bit.ly/2svxQ7r dengan 10 pertanyaan.

\section{Teknik Analisis Data}

Teknis analisis data yang dilakukan dengan memilah-milah data yang sesuai dengan tujuan penelitian, hasil kajiannya disajikan dengan metode deskriptif, dengan menggambarkan menguraikan dan menjelaskan data secara sistematis. Analisis data kualitatif yang akan dilakukan secara interaktif melalui proses data reduction, data display, verification dan kesimpulan (Miles dan Huberman, 1992)

\section{Rencana Pengujian Keabsahan}

Dalam pengujian keabsahan data ini dilakukan dengan Uji kredibilitas yaitu dengan perpanjangan pengamatan, peningkatan ketekunan dalam penelitian, triangulasi, diskusi dengan teman sejawat, analisis kasus negatif dan membercheck (Sugiyono, 2011).

\section{HASIL DAN PEMBAHASAN \\ a. Tim Manajemen}

Sesuai dengan PP Nomor 46/2011 tentang Penilaian Prestasi Kerja PNS dan Perka BKN Nomor 1/2013 tentang Ketentuan Pelaksanaan PP Nomor 46/2011 tentang Penilaian Prestasi Kerja PNS, maka PNS diwajibkan untuk menyusun SKP sebagai dasar penilaian prestasi kerja pegawai. Tujuannya untuk menjamin objektivitas pembinaan PNS yang dilakukan berdasarkan sistem prestasi kerja Pustakawan menyusun SKP berdasarkan pada butir-butir kegiatan yang telah ditetapkan. Dalam setiap butir-butir ditentukan besarnya waktu atau SKR. Dalam butir-butir kegiatan tersebut belum ada besarnya waktu rata-rata, sehingga dibentuklah Tim yang ditunjuk oleh Direktorat Sumber Daya Manusia UGM untuk menentukan besarnya waktu rata-rata setiap 
butir-butir kegiatan. Tim ini terdiri Ketua, Sekretaris dan Anggota.

Untuk mengetahui cara penentuan besarnya SKR tersebut peneliti melakukan wawancara dengan narasumber yaitu Tim Penentu Beban Kerja dan Tim Manajemen Perpustakaan. Narasumber dengan Ketua yaitu Drs. Hindar Purnomo, M.Si., Sri Rumani, SH., SIP, M.Si., dan Wahyu Supriyanto, SE., M.Si. Sedang Tim Manajemen wawancara dengan Kepala Perpustakaan, Kepala Bidang TI dan Jaringan, serta Dra. Nurhayati, MSi.

Daftar Pertanyaan sebagai pedoman dalam wawancara adalah sebagai berikut:

1. Bagaimana cara menentukan besarnya waktu (SKR) pada butir-butir kegiatan sebagai beban kerja dalam SKP

2. Pedoman apa yang digunakan dalam menentukan waktu tersebut

3. Siapa saja yang terlibat dalam menentukan waktu

4. Siapa yang mengambil keputusan dalam menentukan waktu

5. Faktor-faktor apa saja yang digunakan dalam menentukan SKR

6. Adakah kesulitan dalam menentukan waktu SKR

7. Dalam menentukan waktu (SKR) Apakah pernah dilakukan penelitian/survei pada pustakawan

8. Kendala apa yang dihadapi dalam menentukan besarnya waktu

9. Dalam menentukan waktu apakah melibatkan Direktorat SDM UGM?

10. Kalau iya...apa saran dan masukan dari Direktorat SDM

Dari hasil wawancara diperoleh informasi yang sangat berguna dalam penelitian ini yaitu sebagai berikut:

1. Cara menentukan besarnya waktu (SKR) pada butir-butir kegiatan sebagai beban kerja dalam SKP. Cara menentukan besarnya waktu (SKR) pada butir-butir kegiatan sebagai beban kerja dalam SKP berdasarkan kesepakatan dengan Tim dengan mempertimbangkan rata-rata pustakawan melakukan pekerjaan seharihari. Dengan cara mengumpulkan berkas pustakawan yang akan naik pangkat.
2. Pedoman yang digunakan dalam menentukan waktu tersebut. Tidak ada pedoman khusus yang digunakan dalam menentukan besarnya waktu pada setiap butir-butir kegiatan.

3. Yang terlibat dalam menentukan waktu. Yang terlibat dalam menentukan besarnya waktu dalam SKR adalam Tim yang ditunjuk oleh Direktorat SDM UGM, yang terdiri dari Ketua, Sekretaris dan Anggota. Tim Manajemen Perpustakaan tidak ikut terlibat langsung dalam menentukan besarnya beban kerja.

4. Yang mengambil keputusan dalam menentukan waktu, yakni Tim Penentuan Beban Kerja tersebut.

5. Faktor-faktor yang digunakan dalam menentukan SKR yakni Beban Kerja, Waktu Kerja Efektif dalam setahun, Butir-butir Kegiatan

6. Kesulitan dalam menentukan waktu SKR, tidak ada kesulitan dalam menentukan beban kerja tersebut. Akan tetapi kelayakannya perlu dikaji dan dievaluasi.

7. Dalam menentukan waktu (SKR) tidak pernah dilakukan penelitian/survei pada pustakawan. Tim menentukan sendiri dan pustakawan menerima ketentuan yang dibuat oleh Tim tersebut

8. Kendala yang dihadapi dalam menentukan besarnya waktu. Pada dasarnya tidak ada kendala yang berarti yang dihadapi oleh tim, akan tetapi karena waktu dalam menentukan besaran tersebut sangat pendek sehingga kesesuaian perlu diuji dan dievaluasi.

9. Dalam menentukan waktu tidak melibatkan Direktorat SDM UGM. Direktorat SDM mempercayakan pada Tim dari Perpustakaan. Akan tetapi sekretaris SDM pernah menyampaikan secara lisan kepada Ketua Tim bahwa dalam menentukan besaran waktu kebesaran perlu diturunkan/dikecilkan.

\section{b. Pustakawan Ahli}

Hasil penelitian menunjukkan bahwa ada beberapa pustakawan ahli yang mengalami kesulitan dalam menyusun SKP. Kesulitan yang dihadapi pada penentuan jam kerja yang tidak 
sesuai dengan keadaan di lapangan; sebanyak 11 orang pustakawan ahli atau 31,4\%, atau hampir sepertiga dari jumlah pustakawan ahli yang masih mengalami kesulitan dalam memenuhi WKE sebesar 1250 jam. Perlu pengkajian lebih mendalam dalam penentuan beban kerja pada setiap butir-butir kegiatan pada SKP.; Sebanyak 24 orang pustakawan ahli atau $66,7 \%$ yang menyatakan bahwa penentuan waktu pada butirbutir kegiatan dalam SKP tidak sesuai. Ini menjadi salah satu faktor yang menyebabkan sebagian pustakawan ahli masih mengalami kesulitan dalam menyesuaikan antara WKE dengan jumlah angka kredit yang diperlukan; 18 orang pustakawan ahli atau 52,9\% yang menyatakan merasa kesulitan dalam menyesuaikan jumlah angka kredit dengan WKE; Sebanyak 20 orang atau 57,2\% yang menyatakan tidak ada pedoman dalam penentuan Waktu SKR pada butir-butir kegiatan di SKP.

Penentuan beban kerja pada butir-butir dalam SKP diperlukan suatu pedoman sebagai panduan dalam penentuan besarnya SKR. Pedoman bisa dibuat bersama-sama, semua unsur yang ada baik Tim Manajemen Perpustakaan, Direktorat SDM, Tim TI, dan Pustakawan Ahli. Pembuatan dilakukan dengan mengkaji setiap butir kegiatan yang terdapat dalam Peraturan Menteri Pendayagunaan Aparatur Negara dan Reformasi Birokrasi RI No. 9 Tahun 2014 tentang Jabatan Fungsional Pustakawan dan Angka Kreditnya. Hal ini diperlukan dengan tujuan untuk memberi kemudahan pada pustakawan ahli dalam menyusun SKP, sehingga kewajiban dalam memenuhi WKE sebesar 1250 jam setiap tahun sesuai dengan jumlah angka kredit yang dibutuhkan.

Peneliti mengirimkan kuesioner pada 50 pustakawan ahli, dari 50 kuesioner kembali sebanyak 38 orang atau $76 \%$. Sebanyak $76 \%$ atau lebih dari $50 \%$ dari responden yang mengembalikan, hal ini sudah mewakili hasil penelitian. Hasil survei dari kuesioner yang disebarkan sebagai berikut:

Tabel 2. menunjukkan bahwa data pustakawan ahli di UGM sebanyak 51 orang, 1 orang masih berstatus sebagai pengadministrasi perpustakaan sehingga jumlah pustakawan ahli sebanyak 50 orang. Semua pustakawan ahli tersebut sebagai responden dalam penelitian ini. Kuesioner disebarkan sejumlah 50 dan yang diisi dan dikembalikan sebanyak 38 kuesioner. Hasil penelitian menunjukkan responden pria sebanyak 15 orang atau $39,5 \%$ dan responden wanita sebanyak 23 orang atau $60,5 \%$. Hal ini menujukkan jumlah pustakawan ahli berjenis kelamin wanita lebih banyak dibanding pustakawan ahli berjenis kelamin laki-laki, dengan selisih 8 orang atau 21\%. Tabel 2 menunjukkan Perpustakaan UGM tidak mempunyai Pustakawan Utama, Pustakawan Madya sebanyak 5 orang 14,3\%, Pustakawan Muda sebanyak 15 orang atau 49,9\%, dan 15 orang atau 49,9\% Pustakawan Pertama. Tabel ini menunjukkan usia pustakawan ahli masih relatif muda dan menunjukkan tingkat produktifitas dalam bekerja cukup tinggi.

Dari tabel 3 bahwa Jumlah Jam Kerja Pustakawan Ahli dalam SKP 2017 kurang dari 1250 jam selama satu tahun sebanyak 3 orang atau $8,1 \% ; 1250$ jam sebanyak 19 orang atau $51,4 \%$ dan lebih dari 1250 jam sebanyak 15 orang atau $40,5 \%$. Tabel ini menunjukkan masih ada 3 orang pustakawan ahli yang mengalami kesulitan dalam memenuhi WKE sebanyak 1250 jam. Ini menjadi masalah yang harus diselesaikan dengan baik, mencari sebab dan mencari solusi. WKE sebanyak 1250 jam ini menjadi kewajiban bagi setiap PNS dalam membuat SKP. Dari tabel 4 bahwa Jumlah Angka Kredit Pustakawan Ahli dalam SKP 2017 kurang dari 30 selama satu tahun sebanyak 7 orang atau 20\%, antara 30-60 sebanyak 13 orang atau $37,1 \%$ dan lebih dari 60 sebanyak 15 orang atau $42,9 \%$. Tabel 4 menggambarkan bahwa apabila pustakawan ahli bisa memenuhi sejumlah angka kredit yang sudah direncanakan maka kenaikan jabatan seorang pustakawan tidak akan mengalami kesulitan. Jumlah angka kredit sudah cukup untuk kenaikan jabatan setiap 2 tahun sekali.

Dari tabel 5 bahwa Kesulitan Pustakawan Ahli dalam membuat SKP yang menyatakan YA sebanyak 6 orang atau 17,1\%, yang menyatakan TIDAK sebanyak 27 orang atau 77,1 \% dan sebanyak 5 orang atau $5,8 \%$. Hal ini 
menunjukkan bahwa jawaban YA dan jawaban MUNGKIN menjadi perhatian penelitian. Ini merupakan jawaban "abu-abu" yang menunjukkan masih 11 orang pustakawan ahli atau $22,9 \%$ yang mengalami kesulitan dalam membuat SKP. Kesulitan yang dihadapi dikarenakan penentuan jam kerja yang tidak sesuai dengan keadaan di lapangan. Dari tabel 6 bahwa Kesulitan dalam Memenuhi jam kerja minimal $1250 \mathrm{jam} /$ tahun yang menyatakan YA sebanyak 7 orang atau $20 \%$, yang menyatakan TIDAK sebanyak 24 orang atau $68,6 \%$ dan yang menyatakan MUNGKIN sebanyak 4 orang atau $11,4 \%$. Hal ini menunjukkan bahwa jawaban YA dan jawaban MUNGKIN sebanyak 11 orang pustakawan ahli atau 31,4\%, atau hampir sepertiga dari jumlah pustakawan ahli yang masih mengalami kesulitan dalam memenuhi WKE sebesar 1250 jam. Perlu pengkajian lebih mendalam dalam penentuan beban kerja pada setiap butir-butir kegiatan pada SKP.

Dari tabel 7 kesulitan Pustakawan Ahli dalam memenuhi Angka Kredit selama satu tahun yang menyatakan YA sebanyak 10 orang atau $28,61 \%$, yang menyatakan TIDAK sebanyak 17 orang atau $48,6 \%$, yang menyatakan MUNGKIN sebanyak 6 orang atau $17,1 \%$, Diri Sendiri sebanyak 1 orang atau 2,9\% dan Tidak Mungkin sebanyak 1 orang atau 2,9\%. Pustakawan Ahli yang Kesulitan Pustakawan Ahli dalam Memenuhi Angka Kredit selama Satu Tahun yang memberi jawaban YA dan MUNGKIN sebanyak 16 orang atau $45,7 \%$. Hal ini menunjukkan bahwa walau pustakawan ahli bisa memenuhi angka kredit dalam satu tahun tetapi masih merasa mengalami kesulitan. Dari tabel 8 bahwa Kesesuaian Penentuan Waktu pada Butir-Butir Kegiatan dalam SKP yang menyatakan YA sebanyak 13 orang atau 36,1\%, yang menyatakan TIDAK sebanyak 11 orang atau 30,6\%, yang menyatakan MUNGKIN sebanyak 11 orang atau $30,6 \%$, dan ada sebagian yang kurang dengan realitas di lapangan sebanyak 1 orang atau 2,8\%. Hal ini menunjukkan bahwa jawaban TIDAK dan jawaban MUNGKIN sebuah jawaban yang menjadi permasalahan dalam penelitian ini. Sebanyak 24 orang pustakawan ahli atau $66,7 \%$ atau lebih dari setengah dari jumlah pustakawan ahli yang menyatakan bahwa Penentuan Waktu pada Butir-Butir Kegiatan dalam SKP tidak sesuai. Inilah salah satu faktor yang menyebabkan pustakawan ahli masih mengalami kesulitan dalam menyesuaikan antara Waktu Kerja Efektif (WKE) dengan jumlah Angka Kredit yang diperlukan oleh pustakawan ahli.

Dari tabel 9 bahwa Kesulitan dalam Menyesuaikan Jumlah Angka Kredit dengan Jumlah Jam Kerja selama Satu Tahun yang menyatakan YA sebanyak 13 orang atau $38,2 \%$, yang menyatakan TIDAK sebanyak 16 orang atau 47,1\% dan yang menyatakan MUNGKIN sebanyak 5 orang atau 14,7\%. Hal ini menunjukkan bahwa jawaban TIDAK dan jawaban MUNGKIN sebuah jawaban yang menjadi permasalahan dalam penelitian ini. Sebanyak 18 orang pustakawan ahli atau 52,9\% yang menyatakanmerasa kesulitan dalam menyesuaikan Jumlah Angka Kredit dengan Jumlah Jam Kerja selama Satu Tahun. Dari tabel 10 bahwa Faktor Penghambat Pustakawan Ahli dalam Membuat SKP yang menyatakandiri Sendiri sebanyak 13 orang atau $35,1 \%$, yang menyatakankarena Sistem sebanyak 16 orang atau $43,2 \%$, yang menyatakan karena Pimpinan sebanyak 3 orang atau $8,1 \%$ dan yang menyatakan karena faktor lainnya sebanyak 5 orang $13,5 \%$.

Dari tabel 11 bahwa Ada Pedoman dalam Penetuan Waktu (SKR) pada Butir-Butir Kegiatan di SKP yang menyatakan YA sebanyak 25 orang atau $42,9 \%$, yang menyatakan TIDAK sebanyak 12 orang atau 34,3\% dan yang menyatakan MUNGKIN sebanyak 8 orang atau 22,9\%. Dari tabel 12 bahwa Ada Tugas Penunjang/Tugas Tambahan Pustakawan Ahli dalam SKP yang menyatakan YA sebanyak 25 orang atau $71,4 \%$, yang menyatakan TIDAK sebanyak 9 orang atau $25,7 \%$ dan yang menyatakan MUNGKIN sebanyak 1 orang atau $2,9 \%$. Untuk memenuhi jam WKE pustakawan menambah jumlah jam kerja efektif untuk memenuhi kewajiban sebanyak 1250. Apabila tidak menambah jam tambahan maka pustakawan ahli kesulitan dalam memenuhi WKE tersebut. 
Pertanyaan ke 11 tentang Berapa jumlah Jam Kerja "Tugas Penunjang" Anda dalam satu tahun, dari 38 pustakawan Ahli yang mengembalikan kuesioner ada 12 orang yang mengisi pertanyaan ini atau 24\%. Daftar isian dapat dilihat pada tabel 14.

Dari 38 pustakwan ahli yang megisikan jumlah jam tambahan sebanyak 12 orang, satu orang tidak memerlukan jam tambahan, satu orang tidak tahu (karena membuka portal HRIS yang diminta) dan 10 orang mengisikan jumlah jam tambahan diperlukan. Jumlah jam tambahan bervariasi mulai dari 25 jam sampai 1647 jam. Dari data tersebut apabila dijumlah sebesar 2065 jam dibagi 10 rata-rata menunjukkan jumlah jam tambahan yang diperlukan pustakawan ahli relatif cukup besar yaitu lebih dari 206,5 jam untuk satu tahun atau sekitar 16,52\% dari total WKE 1250 jam.

Dari 50 pustakawan Ahli ada 12 orang yang mengisi pertanyaan ini atau 24\% (Tabel 15).

Ada sebanyak 12 saran yang masuk, 1 pernyataan Bagus tentang SKP yang ada dan 1 pernyataan untuk memotivasi diri untuk mendapatkan angka kredit yang bagus dengan memanfaatkan jam kerja yang ada. Tetapi ada 10 pernyataan yang menyatakan tentang perlunya evaluasi dan pembenahan SKR yang ada (Tabel 16).

\section{E. KESIMPULAN}

Berdasarkan pembahasan dapat disimpulkan bahwa 1) telah dibentuk tim untuk penentuan SKR yang terdiri dari Ketua, Sekretaris dan Anggota; 2) masih ada pustakawan ahli yang mengalami kesulitan dalam menyesuaikan jumlah angka kredit dengan jumlah jam kerja efektif selama satu tahun. Hal ini disebabkan dalam menentukan besarnya SKR belum ada pedoman khusus yang digunakan sehingga penentuan dilakukan berdasarkan kesepakatan tim yang ada; penentuan SKR dalam butir-butir kegiatan belum semua sesuai dengan kegiatan yang ada di lapangan.

Berdasarkan kesimpulan di atas, saran yang diajukan sebagai berikut sebaiknya Tim membuat pedoman untuk menentukan besarnya beban kerja pada SKP, dalam menentukan besarnya SKR sebaiknya dilakukan workshop/seminar yang terdiri dari Tim SKP, Direktorat SDM, Tim Penilai Angka Kredit dan Pustakawan untuk mendapat masukan dari berbagai sumber supaya besaran SKR dapat disesuaikan dengan Angka Kredit yang dibutuhkan; SKP sudah berlangsung selama 4 tahun, perlu ditinjau ulang dan dievaluasi untuk perbaikan.

\section{DAFTAR PUSTAKA}

Aminudin, M. (2007). Evaluasi rencana lokasi pemindahan terminal induk KM.6 Banjarmasin (Tesis). Yogyakarta: MPKD Universitas Gadjah Mada.

Anonim. (2014). Mengenal profesi pustakawan. Malang: Universitas Brawijaya. Diakses 12 J u n i , $\quad 2017, \quad$ d a r i http://lib.ub.ac.id/author/admin

Aprilia, H. (2009). Evaluasi pelaksanaan program transmigrasi lokal model ring I pola tani nelayan di Bugel, kec. Panjatan, kab. Kulon Progo dan Gesing, kec. Panggang kab. Gunung Kidul. (Tesis). Yogyakarta: MPKD Universitas Gadjah Mada.

Badan Kepegawaian Negara. (2011). Peraturan Pemerintah RI No.46 Tahun 2011 tentang penilaian prestasi kerja pegawai negeri sipil. Jakarta:Badan Kepegawaian Negara.

Badan Perencanaan Pembangunan Nasional. (2006). Peraturan Pemerintah No 39 Tahun 2006 tentang tata cara pengendalian dan evaluasi pelaksanaan rencana pembangunan. Jakarta:

Bryan, C. \& Louis G. W. (1987). Manajemen pembangunan untuk negara berkembang. LP3ES. Jakarta.

Menteri Pendayagunaan Aparatur Negara. (2014). Peraturan Menteri Pendayagunaan Aparatur Negara dan Reformasi Birokrasi RI No. 9 Tahun 2014 tentang jabatan fungsional pustakawan dan angka kreditnya. Jakarta.

Miles, M. R., Huberman, A. M.,; (1992). Analisa data kualitatif. Diterjemahkan oleh: Rohidi, T. R., ; Mulyarto. Jakarta: Universitas Indonesia. 
Nashihuddin, W. \& Aulianto, D. R., (2015). Strategi peningkatan komptensi dan profesionalisme pustakawan di perpustakaan khusus, Jurnal Perpustakaan Pertanian, 24(2), 51-58.

Republik Indonesia. (2007). Undang-Undang No. 43 Tahun 2007 tentang perpustakaan. Jakarta: CV. Tamita Utama

Romadhoni, L. C., Asmony, T., \& Suryatni, M. (2015). Pengaruh beban kerja, lingkungan kerja, dan dukungan sosial terhadap Burnout pustakawan di kota Mataram, Jurnal Ilmu Perpustakaan, Informasi dan Kearsipan Khizanah Al-Hikmah, 3(2), 125-145.
Sugiyono. (2011). Metode penelitian kuantitatif :Kualitatif dan R\&D. Bandung: Alfabeta.

Toyang, D. \& Prajarto, N.. (2007). Pengaruh kepemimpinan, kualitas SDM, dan budaya organisasi terhadap optimalisasi kinerja pegawai di Perpustakaan Nasional RI Jakarta, Berkala Ilmu Perpustakaan, III (7), 12-24. 


\section{DAFTAR GAMBAR}

\section{Sasaran Kerja Pegawai (SKP Target)}

Informasi SKP

Periode

Tanggal Dibuat

Status Verifikasi

Jumlah Angka Kredit

Jumlah PBK

$$
\begin{aligned}
& 01 \text { Januari } 2017 \text { s.d. } 31 \text { Desember } 2017 \\
& 21 \text { Maret } 2017 \\
& \text { Disetujui () }
\end{aligned}
$$

\begin{tabular}{|c|c|c|c|c|c|}
\hline No. & & PEJABAT PENILAI & No. & \multicolumn{2}{|c|}{ II. PEGAWAI YANG DINILAI } \\
\hline 1. & Nama & & 1. & Nama & \\
\hline 2. & NIP & 197110161994121001 & 2. & NIP & 197012141993032001 \\
\hline 3. & Pangkat/ Gol. Ruang & Penata Tingkat I (Gol. III/d) & 3. & Pangkat/ Gol. Ruang & Penata Tingkat I (Gol. III/d) \\
\hline 4. & Jabatan & Kepala Bidang Pelayanan Perpustakaan & 4. & Jabatan & $\begin{array}{l}\text { Jabatan Fungsional Tertentu } \\
\text { Pustakawan Muda }\end{array}$ \\
\hline
\end{tabular}

89.80

WPT: 1268 Jam, WKE: $1250 \mathrm{Jam}$, Selisih: 18

Gambar 1. Contoh SKP Target

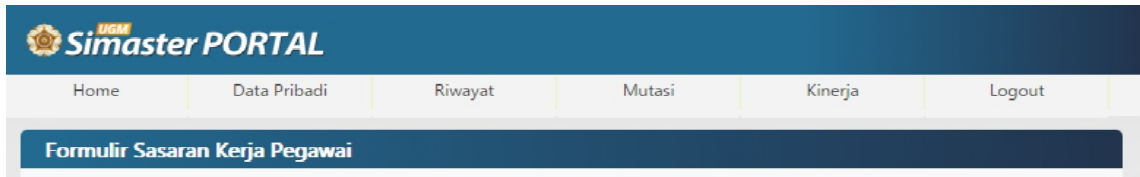

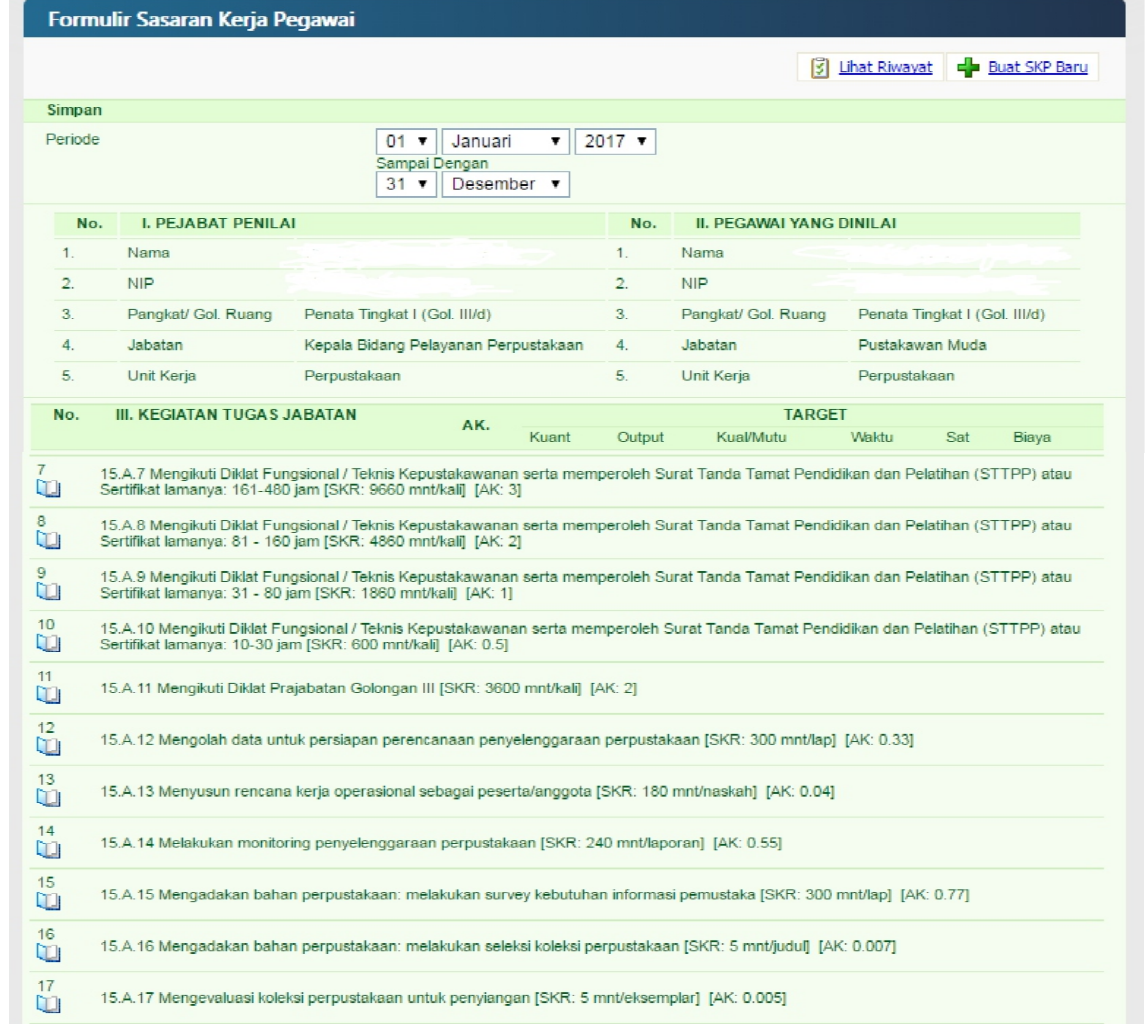

Gambar 2 Contoh butir-butir kegiatan dalam SKP Target 


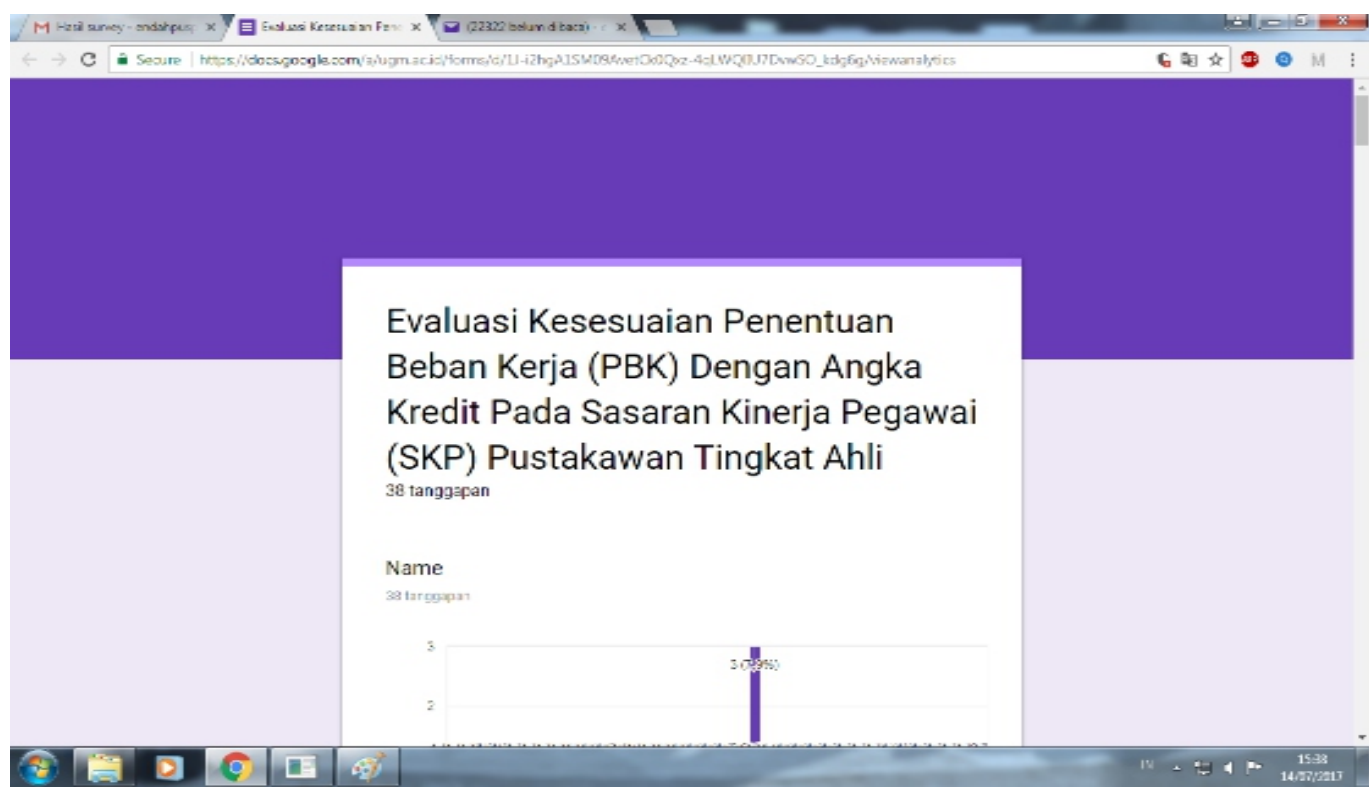

Gambar 3. Form Kuesioner Online

\section{DAFTAR TABEL}

Tabel 1. Contoh data WPT Pustakawan Ahli

\begin{tabular}{|c|c|c|c|c|}
\hline Pustakawan & $\begin{array}{l}\text { Pangkat, } \\
\text { Golongan }\end{array}$ & Tahun & WPT & $\begin{array}{l}\text { Angka } \\
\text { Kredit }\end{array}$ \\
\hline \multirow[t]{4}{*}{$\mathrm{E}$} & $\mathrm{III} / \mathrm{d}$ & 2017 & 1268 & 89,80 \\
\hline & & 2016 & 1254 & 59.67 \\
\hline & & 2015 & 1255 & 38.99 \\
\hline & & 2014 & 5575 & 100.55 \\
\hline \multirow[t]{4}{*}{$\mathrm{U}$} & $\begin{array}{l}\text { Penata Muda Tk. } \\
\text { I/III/b }\end{array}$ & 2017 & 1647 & 90.065 \\
\hline & & 2016 & 1250 & 99.335 \\
\hline & & 2015 & 1251 & 52.82 \\
\hline & & 2014 & 1250 & 24.655 \\
\hline \multirow[t]{4}{*}{$\mathrm{N}$} & $\begin{array}{l}\text { Penata Muda Tk. } \\
\text { I/III/b }\end{array}$ & 2017 & 1250 & 88.09 \\
\hline & & 2016 & 1250 & 39.91 \\
\hline & & 2015 & 1250 & 47.08 \\
\hline & & 2014 & 5846 & 71.21 \\
\hline
\end{tabular}

Tabel 2. Daftar Pustakawan Ahli berdasarkan Jenis Kelamin

\begin{tabular}{lcc}
\hline \multicolumn{1}{c}{ Jenis Kelamin } & Jumlah & \% \\
\hline Pria & 15 orang & 39,5 \\
Wanita & 23 orang & 60,5 \\
& & \\
\hline Jumlah & 38 orang & $100 \%$ \\
\hline
\end{tabular}


Tabel 3. Daftar Pustakawan Ahli berdasarkan Jenjang Jabatan

\begin{tabular}{lcc}
\hline \multicolumn{1}{c}{ Jabatan } & Jumlah & $\%$ \\
\hline Pustakawan Utama & 0 orang & 0 \\
Pustakawan Madya & 8 orang & 14,2 \\
Pustakawan Muda & 15 orang & 42,9 \\
Pustkawan Pertama & 15 orang & 42,9 \\
& & \\
\hline Jumlah & 38 orang & $100 \%$ \\
\hline
\end{tabular}

Tabel 4. Jumlah Jam Kerja Pustakawan Ahli dalam SKP 2017

\begin{tabular}{lcc}
\hline \multicolumn{1}{c}{ Jumlah Jam } & Pustakawan & $\%$ \\
\hline Kurang dari 1250 jam & 3 orang & 8,1 \\
1250 jam & 19 orang & 51,4 \\
Lebih dari 1250 jam & 15 orang & 40,5 \\
\hline Jumlah & & $100 \%$ \\
\hline
\end{tabular}

Tabel 5. Jumlah Angka Kredit Pustakawan Ahli pada S KP 2017

\begin{tabular}{lcc}
\hline \multicolumn{1}{c}{ Jumlah Angka Kredit } & Jumlah Pustakawan & $\%$ \\
\hline Kurang dari 30 & 7 orang & 20 \\
$30-60$ & 13 orang & 37,1 \\
Lebih dari 60 & 15 orang & 42,9 \\
\hline Jumlah & & $100 \%$ \\
\hline
\end{tabular}

Tabel 6. Kesulitan Pustakawan Ahli dalam Membuat SKP

\begin{tabular}{lcc}
\hline \multicolumn{1}{c}{ Jawaban Kesulitan } & Jumlah Pustakawan & $\%$ \\
\hline Ya & 6 orang & 17,1 \\
Tidak & 27 orang & 77,1 \\
Mungkin & 5 orang & 5,8 \\
\hline & 38 orang & $100 \%$ \\
\hline
\end{tabular}

Tabel 7. Kesulitan Pustakawan Ahli dalam Memenuhi Jam Kerja Minimal 1250 jam/tahun

\begin{tabular}{lcc} 
Jawaban Kesulitan & Jumlah Pustakawan & $\%$ \\
& & \\
& 8 orang & 20,0 \\
nk & 25 orang & 68,6 \\
& 5 orang & 11,4 \\
\hline
\end{tabular}


Tabel 8. Kesulitan Pustakawan Ahli dalam Memenuhi Angka Kredit selama Satu Tahun

\begin{tabular}{lcc}
\hline \multicolumn{1}{c}{ Jawaban Kesulitan } & Jumlah Pustakawan & $\mathbf{\%}$ \\
\hline Ya & 10 orang & 28,6 \\
Tidak & 17 orang & 48,6 \\
Mungkin & 6 orang & 17,1 \\
Diri Sendiri & 1 orang & 2,9 \\
Tidak Mungkin & 1 orang & 2,9 \\
\hline
\end{tabular}

Tabe1 9. Ke sesuaian Penentuan Waktu pada Butir-Butir Kegiatan dalam SKP

Jawaban Kesulitan Jumlah Pustakawan $\quad \%$

\begin{tabular}{lcc}
\hline Ya & 13 orang & 36,1 \\
Tidak & 11 orang & 30,6 \\
Mungkin & 11 orang & 30,6 \\
Ada sebagian yang kurang dengan & 1 orang & 2,8 \\
realitas di lapangan & & \\
\hline
\end{tabular}

Tabel 10. Kesulitan dalam Menyesuaikan Jumlah Angka Kredit dengan Jumlah Jam Kerja selama Satu Tahun

\begin{tabular}{lcc}
\hline \multicolumn{1}{c}{ Jawaban Kesulitan } & Jumlah Pustakawan & $\mathbf{\%}$ \\
\hline Ya & 13 orang & 38,2 \\
Tidak & 16 orang & 47,1 \\
Mungkin & 5 orang & 14,7 \\
\hline
\end{tabular}

Tabel 11. Faktor Penghambat Pustakawan Ahli dalam Membuat SKP

\begin{tabular}{lcc}
\hline \multicolumn{1}{c}{ Jawaban Kesulitan } & Jumlah Pustakawan & $\mathbf{\%}$ \\
\hline Diri Sendiri & 13 orang & 35,1 \\
Sistem & 16 orang & 43,2 \\
Pimpinan & 3 orang & 8,1 \\
Lainnya & 5 orang & 13,5 \\
\hline
\end{tabular}

Tabel 12. Pedoman dalam Penetuan Waktu (SKR) pada Butir -Butir Kegiatan di SKP

\begin{tabular}{lcc}
\hline \multicolumn{1}{c}{ Jawaban Kesulitan } & Jumlah Pustakawan & $\mathbf{\%}$ \\
\hline Ya & 25 orang & 42,9 \\
Tidak & 12 orang & 34,3 \\
Mungkin & 8 orang & 22,9 \\
\hline
\end{tabular}


Tabel 13. Tugas Penunjang/Tugas Tambahan Pustakawan Ahli dalam SKP

\begin{tabular}{lcc}
\hline \multicolumn{1}{c}{ Jawaban Kesulitan } & Jumlah Pustakawan & $\mathbf{\%}$ \\
\hline Ya & 25 orang & 71,4 \\
Tidak & 9 orang & 25,7 \\
Mungkin & 1 orang & 2,9 \\
\hline
\end{tabular}

Tabel 14. Jumlah Jam Tugas Penunjang/ Tugas Tambahan Pustakawan Ahli dalam SKP

\begin{tabular}{cc}
\hline Responden ke- & Jumlah Jam \\
\hline 1 & 82 \\
2 & 103 \\
3 & $200-250$ \\
4 & 93 \\
5 & 1647 \\
6 & 25 \\
7 & 240 \\
8 & $20 \%$ \\
9 & 400 \\
10 & 0 \\
11 & 250 \\
12 & Tidak tahu \\
\hline
\end{tabular}

Tabel 15. Jumlah Jam Kerja dan Angka Kredit Pustakawan Ahli Tahun 2014-2017

\begin{tabular}{|c|c|c|c|c|c|c|c|c|}
\hline \multirow{3}{*}{$\begin{array}{c}\text { Responden } \\
\text { ke- }\end{array}$} & \multicolumn{8}{|c|}{ Sasaran Kinerja Pegawai (SKP) } \\
\hline & \multicolumn{4}{|c|}{ Jumlah Jam Kerja } & \multicolumn{4}{|c|}{ Jumlah Angka Kredit } \\
\hline & 2014 & 2015 & 2016 & 2017 & 2014 & 2015 & 2016 & 2017 \\
\hline 1 & - & - & - & - & 92,73 & 41,10 & 138,05 & 81,17 \\
\hline 2 & 2091 & 1250 & 1251 & 1250 & 25 & 32 & 54 & 53 \\
\hline 3 & - & - & - & - & 24,39 & 27,26 & 45,15 & 60,25 \\
\hline 4 & 5846 & 1250 & 1250 & 1250 & 71,21 & 47,08 & 39,31 & 88,09 \\
\hline 5 & 1251 & 1250 & 1254 & 1119 & 43,05 & 64,15 & 25,64 & 25,81 \\
\hline 6 & - & - & - & - & 239,17 & 58,84 & 84,07 & 83,05 \\
\hline 7 & 1252 & 1251 & 1260 & 1250 & $\begin{array}{c}\text { Belum } \\
\text { pustakawan }\end{array}$ & 78.04 & 74.21 & 68.25 \\
\hline 8 & 1250 & 1265 & 1250 & 1250 & - & - & - & - \\
\hline 9 & & & & & 22.70 & 31.23 & - & - \\
\hline 10 & - & - & - & - & 42.8363 & 25.5859 & 37.587, & 77.27 \\
\hline 11 & \multicolumn{8}{|c|}{ karena sistem tdk bisa membuka SKP di hris.ugm.ac.id } \\
\hline 12 & 1189 & 1281 & 1256 & 1258 & 177,38 & 47,46 & 56,60 & 58,79 \\
\hline 13 & - & - & - & - & 83,27 & 97,50 & 79,57 & 65,98 \\
\hline 14 & 1250 & 1250 & 1250 & 1250 & 112,11 & 27,52 & 50,60 & 68,25 \\
\hline 15 & 1260 & 1250 & 1255 & 1252 & 47,56 & 81,77 & 96,53 & 94,23 \\
\hline 16 & 5696 & 1260 & 1253 & 1251 & 27,085 & 45,3 & 40,69 & 84,45 \\
\hline 17 & 11809 & 1377 & 1513 & 1187 & 87,75 & 15,49 & 27,40 & 34,10 \\
\hline 18 & $\begin{array}{c}\text { Belum } \\
\text { pustakawan }\end{array}$ & 1250 & 1250 & 1250 & $\begin{array}{c}\text { Belum } \\
\text { pustakawan }\end{array}$ & 13,48 & 12,60 & 15,63 \\
\hline
\end{tabular}


Tabel 16. Daftar Saran dan Masukan dari Pustakawan Ahl i

\begin{tabular}{|c|c|}
\hline $\begin{array}{l}\text { Responden } \\
\text { ke- }\end{array}$ & Saran dan masukan \\
\hline- & $\begin{array}{l}\text { - SKR mohon lebih disesuaikan dengan kenyataan di lapangan } \\
\text { - Ada informasi dari pimpinan terkait program kerja Unit, sehingga kita dapat } \\
\text { memasukkannya sebagai target dalam SKP }\end{array}$ \\
\hline $\mathrm{Fc}$ & Form SKP sebaiknya direvisi yg lebih rasional \\
\hline $\mathrm{Pe}$ & Penempatan pustakawan sesuai dg jabatan fungsional pustakawan \\
\hline 4 & Bagus \\
\hline $\begin{array}{l}\mathrm{H} \\
\mathrm{bi}\end{array}$ & $\begin{array}{l}\text { Harus bisa memotivasi diri untuk mendapatkan angka kredit yang mentes.banyak celah yang } \\
\text { bisa dimanfaatkan agar jam kerja serta angka kredit terpenuhi }\end{array}$ \\
\hline $\begin{array}{l}\mathrm{Pe} \\
\mathrm{Pl}\end{array}$ & $\begin{array}{l}\text { Perlu ada fleksibil itas pembuatan SKP sesuai dengan situasi yang ada di lingkungan } \\
\text { Pustakawan masing-masing dan beban kerja atau tupoksi yang diberikan oleh atasan. }\end{array}$ \\
\hline $\begin{array}{l}\mathrm{Pe} \\
12 \\
\mathrm{ja} \\
\mathrm{pe}\end{array}$ & $\begin{array}{l}\text { Peraturan yg baru utk rincian tugas utama sulit utk dilaksanakan shg susah utk memenuhi } \\
1250 \text { jam. Sdgkan jika lbh bnyk tugas limpahan atau tambahan yg digunakan utk memenuhi } \\
\text { jam, nilai akan jelek. Sdgkan bnyk pekerjaan yg tdk bisa dimasukkan ke golongan pust } \\
\text { pertama }\end{array}$ \\
\hline 8 & Point' pekerjaan utama dilevel pust ahli sulit utk bisa dilaksanakan Krn bnyk \\
\hline $\begin{array}{l}\text { pe } \\
\text { jo }\end{array}$ & $\begin{array}{l}\text { pekerjaan yg tdk sesuai dg jobdesk, bnyk tambahan pekerjaan dr pimpinan yg tdk sesuai } \\
\text { jobdesk. Sdgkan jika mengambil dr tgs limpahan dan penunjang nilai skp jd kecil. }\end{array}$ \\
\hline 10 & Unsur penunjang perlu diperjelas \\
\hline $\begin{array}{ll}\text { de } \\
\text { de } \\
11\end{array}$ & $\begin{array}{l}\text { SKP jangan dijadikan angka kredit pustakawan karena SKP ad alah sesuatu yang berbeda } \\
\text { dengan profesi pustakawan. SKP tolok ukurnya adalah jam efektif bekerja. } \\
\text { 11. belum ada saran dan masukan }\end{array}$ \\
\hline 12 & Perlu penyesuaian SKR pada butir-butir kegiatan pustakawan dengan juknis terbaru \\
\hline
\end{tabular}

